\title{
Uczestnictwo w sieci międzyorganizacyjnej - katalizator czy bariera w procesach odnowy strategicznej?
}

\section{Participation in an interorganizational networks - a catalyst or a barrier to the process of strategic renewal?}

\author{
Janusz Marek Lichtarski \\ Uniwersytet Ekonomiczny we Wrocławiu, e-mail: janusz.lichtarski@ue.wroc.pl
}

\begin{abstract}
Streszczenie
Odnowa strategiczna organizacji jest bardzo złożonym procesem. Jej powodzenie zależy od wielu czynników wewnętrznych i zewnętrznych. Jednym z tych czynników jest uczestnictwo w sieci międzyorganizacyjnej. Czynnik ten może wspomagać i ułatwiać procesy odnowy lub stanowić barierę dla transformacji. Celem artykułu jest identyfikacja wpływu sieci międzyorganizacyjnej na procesy odnowy jej uczestników. Można przyjąć konkluzję, że sieć będzie sprzyjać odnowie strategicznej, jeśli wynikające z tych zmian korzyści będą dotyczyć nie tylko transformowanego podmiotu, lecz także całej sieci. W przeciwnym razie sieć może stanowić barierę procesu odnowy strategicznej organizacji węzłowej.
\end{abstract}

Słowa kluczowe: odnowa strategiczna, uwarunkowania, sieci międzyorganizacyjne.

\begin{abstract}
The strategic renewal of organization is a very complex process. Its success depends on many internal and external factors. One of those factors is the participation in an interorganizational network. The factor can enhance and facilitate the renewal processes or be a barrier to transformations. The goal of the article is to identify the impact of interorganizational networks on renewal processes of the network's participants. It can be concluded that the network will foster the strategic renewal while the benefits of the changes concern not only a transformed organization but also the entire network. Otherwise, a network may be a barrier to the process of strategic renewal of a nodal organization.
\end{abstract}

Keywords: strategic renewal, determinants, interorganizational networks. 


\section{Wstęp}

Sieci międzyorganizacyjne stają się nieodłącznym zjawiskiem charakteryzującym współczesną gospodarkę, a ich uczestnikami (węzłami, aktorami) są podmioty bardzo zróżnicowane pod względem specyfiki założonych celów, wielkości, przedmiotu i zasięgu działalności oraz formy prawno-organizacyjnej. Skupiając dużą liczbę różnorodnych podmiotów, reprezentujących wiele sektorów gospodarki, sieci międzyorganizacyjne stanowią wyzwanie dla teorii i praktyki zarządzania, odgrywając jednocześnie bardzo ważną rolę w rozwoju globalnej gospodarki.

Jednocześnie dynamiczne otoczenie konkurencyjne i trwający od kilku lat kryzys ekonomiczny wymuszają na przedsiębiorstwach przeprowadzanie licznych zmian, $w$ tym również transformacji kluczowych elementów dotychczas stosowanych modeli biznesowych. Dokonywane zmiany dotyczą więc m.in. domeny działalności, oferowanych produktów, rynków docelowych, strategii, struktury organizacyjnej, łańcucha wartości itd. Ogół treści, procesu i efektów, tak szerokich pod względem zakresu, kompleksowych i istotnych dla organizacji zmian modelu biznesowego, określany jest mianem odnowy strategicznej przedsiębiorstwa [Cyfert, Bełz, Wawrzynek 2014].

Jeśli połączyć obydwie wskazane wcześniej tendencje, tj. dynamiczny rozwój sieci międzyorganizacyjnych oraz potrzebę przeprowadzania odnowy strategicznej przedsiębiorstw, nasuwają się pytania: Czy uczestnictwo w sieci międzyorganizacyjnej stanowi katalizator, czy barierę dla procesów odnowy strategicznej organizacji węzłowych? W jakich sytuacjach sieć (jako całość) wspomaga i katalizuje procesy odnowy strategicznej jej uczestników, a w jakich sytuacjach stanowi barierę, spowalnia procesy transformacyjne i osłabia pożądane efekty tych zmian? Celem niniejszego opracowania jest próba identyfikacji wpływu uczestnictwa podmiotu w sieci międzyorganizacyjnej na przebieg, treść oraz efekty zmian kluczowych składników modelu biznesowego. Identyfikację badanych na gruncie teoretycznym uwarunkowań poprzedza przedstawienie wybranych definicji i ujęć zjawiska odnowy strategicznej przedsiębiorstwa oraz istoty, cech i rodzajów sieci międzyorganizacyjnych.

\section{Odnowa strategiczna - próba przybliżenia pojęcia}

Odnowa strategiczna definiowana jest jako zjawisko, w którym zasadniczo zmienia się zawartość i proces strategii, pociągając za sobą wielowymiarowe zmiany w zakresie relacji podmiotu z otoczeniem, zasobów i możliwości, struktury organizacyjnej, rutyny i procesów decyzyjnych. Są to zmiany adaptacyjne, zasadnicze i nieodwracalne, potrzebne do przetrwania i funkcjonowania w dłuższym okresie [Agarwal, Helfat 2009]. Niektórzy autorzy podkreślają nie tylko znaczenie zmian dostosowawczych, opartych na dogłębnej analizie otoczenia, lecz także potrzebę przeprowadzenia zmian wyprzedzających, bazujących głównie na prognozach [Banaszyk, Cyfert 2007].

Odnowa strategiczna polega więc na wprowadzaniu dostosowawczych lub antycypacyjnych zmian w ramach kluczowych składników modelu biznesowego, tj. strategii, łańcucha warto- ści, struktury organizacyjnej, powiązań z otoczeniem itd. Zmiany te mają szeroki zakres, a ich efekty są wielowymiarowe i mają istotne znaczenie dla istnienia i dalszego rozwoju danej organizacji. Warto podkreślić, że odnowa strategiczna niekoniecznie oznacza zmiany o charakterze radykalnym (w ujęciu Hammera i Champy'ego), polegające na szybkiej i całkowitej reorganizacji podmiotu metodą prognostyczną - tzw. nieciągła odnowa strategiczna (discontinuous shift). Proces odnowy strategicznej może być realizowany również inkrementalnie, zgodnie z założeniami założenia CPI (continuous proces improvement). W takim przypadku mówimy o tzw. ewolucyjnej lub ciągłej odnowie strategicznej organizacji [Basu 2011].

Ze względu na charakter przeprowadzanych zmian i ich źródła wyróżnić można odnowę strategiczną wewnętrzną i zewnętrzną [Capron, Mitchell 2009]. W pierwszym przypadku zasoby i potencjał rozwijane są wewnątrz organizacji (internal development), w drugim pozyskiwane są z otoczenia i włączane do organizacji (insourcing) za pomocą fuzji, przejęć czy aliansów. Skuteczność przedstawionych modeli odnowy strategicznej uzależniona jest sytuacyjnie, a wybór ścieżki zależy od wielu czynników, w tym m.in. pozycji konkurencyjnej podmiotu, rodzaju pozyskiwanych zasobów, ich dostępności (rzadkości), presji czasu czy poziomu akceptacji ryzyka przeprowadzanych zmian.

Często przywoływanym w literaturze przykładem skutecznego procesu odnowy strategicznej przedsiębiorstwa, które odnosi sukcesy właśnie dzięki zasadniczej zmianie modelu biznesowego, jest firma IBM. Działający od kilku dekad na konkurencyjnym i wymagającym pod względem technologii rynku producentów sprzętu komputerowego IBM w ciągu kilku lat przekształcił się w dostawcę usług IT, $\mathrm{w}$ zasadzie porzucając i wyprzedając swój dotychczasowy biznes [Agarwal, Helfat 2009]. Przykład ten doskonale obrazuje zakres przeprowadzonych zmian w obszarze strategii (celów), produktów/usług, klientów, zasięgu działania, struktury organizacyjnej i kluczowych kompetencji. Obecny model biznesowy IBM różni się od tego sprzed transformacji niemal w każdym aspekcie, wspólne są branża i grupa klientów, z którymi firma wcześnie wypracowała liczne kontakty.

\section{Sieć międzyorganizacyjna - istota i rodzaje}

Powstanie i rozwój sieci międzyorganizacyjnych to następstwo rosnącej specjalizacji podmiotów, dynamicznego postępu techniczno-technologicznego, globalizacji gospodarki i podejmowania przez organizacje coraz trudniejszych (bardziej ambitnych, złożonych) wyzwań w sferze biznesu i usług publicznych [Gulati, Gargiulo 1999; Milward, Provan 2006]. Rozwój sieci międzyorganizacyjnych ma również uzasadnienie ekonomiczne, bowiem na dynamicznym i konkurencyjnym rynku koordynacja rynkowa lub formy pośrednie często okazują się bardziej efektywne niż typowa koordynacja hierarchiczna [Williamson 1998].

Pojęcie sieci międzyorganizacyjnej nie jest jednoznacznie zdefiniowane w naukach o zarządzaniu. Najczęściej zjawisko to określa się jako układ dwóch lub większej liczby podmiotów połączonych długoterminowymi relacjami [Thorelli 1986], 
jednak takie ujęcie należy zawęzić, ponieważ każda organizacja, będąc systemem otwartym, pozostaje w mniej lub bardziej trwałych relacjach z otoczeniem [Czakon 2012]. Demarkacja nie jest w tym przypadku łatwa, a pomocna w zdefiniowaniu pojęcia sieci międzyorganizacyjnej jest charakterystyka cech węzłów i relacji. W ramach tej charakterystyki najczęściej wskazuje się m.in. na dobrowolny charakter uczestnictwa, trwałość powiązań, współdziałanie uczestników, częstotliwość wymiany i jej rynkowy charakter, wyspecjalizowanie, posiadanie komplementarnych zasobów [Niemczyk, Stańczyk-Hugiet, Jasiński (red.) 2012].

A zatem sieć międzyorganizacyjna może być zdefiniowana jako zbiór kilku lub większej liczby podmiotów, niezależnych pod względem prawnym i ekonomicznym, koordynowanych za pomocą mechanizmów rynkowych i pozostających w relacjach współdziałania (lub koopetycji). Uczestnicy sieci określają wspólne cele, wymieniają się informacjami i wzajemnie od siebie uczą oraz realizują poszczególne działania w łańcuchu wartości. Działania uczestników sieci są integrowane i koordynowane przede wszystkim za pomocą mechanizmów rynkowych i społecznych (znacznie rzadziej hierarchicznych). Ponadto uczestnicy posiadają unikatowe zasoby i komplementarne umiejętności, co skłania do podejmowania i rozwoju współpracy i sprzyja osiąganiu synergii w skali całej sieci.

W literaturze zaproponowano wiele typologii sieci międzyorganizacyjnych uwzględniających różne kryteria podziału i rodzaje sieci, w tym m.in. [Czakon 2012; Krupski (red.) 2005; Milward, Provan 2006; Borgatti, Foster 2003; Uzzi, Lancaster 2003]':

- ze względu na okoliczności powstania: sieci ukształtowane w wyniku podziału większego podmiotu, sieci outsourcingowe i franczyzowe,

- ze względu na stopień centralizacji: sieci monocentryczne, policentryczne i rozproszone,

- ze względu na gęstość: sieci gęste, liniowe i klastrowe,

- ze względu na rodzaj realizowanych zadań: sieci wymiany informacji, wymiany i tworzenia wiedzy, rozwoju, rozwiązywania złożonych problemów, produkcyjne dostarczania usług, dyfuzji innowacji,

- ze względu na usytuowanie w łańcuchu wartości i intensywność konkurencji wewnętrznej: sieci kooperacyjne pionowe, poziome, wielokierunkowe, a także sieci koopetycyjne.

Analiza poszczególnych typów sieci międzyorganizacyjnej wskazuje na bardzo dużą różnorodność tej grupy zjawisk, a ich pogłębiona charakterystyka potwierdza, że typ/rodzaj sieci w dużym stopniu wpływa na funkcjonowanie organizacji węzłowych oraz zmiany dokonywane w ich wnętrzu.

\section{Sieć międzyorganizacyjna - katalizator czy bariera transformacji węzłów?}

Sieci międzyorganizacyjne z reguły przedstawiane są w kontekście rozwiązań sprzyjających poprawie przepływu informacji i wymiany wiedzy, uzupełnianiu się i rozwojowi istotnych kompetencji oraz tworzeniu wartości dodanej, nie tylko w relacjach pomiędzy podmiotami będącymi uczestnikami sieci, lecz także na płaszczyźnie intraorganizacyjnej, czyli poprawie komunikacji i uczenia się wewnątrz organizacji węzłowych [Castels 2010; Madhavan, Koka, Prescott 1998; Argote 1999; Powell, Koput, Smith-Doerr 1996]. Powodzenie strategicznej transformacji modelu biznesowego w dużym stopniu zależy od szybkości i sprawności wymienionych wcześniej procesów, można więc wnioskować na tej podstawie, że sieć (uczestnictwo w niej) może być czynnikiem facylitującym i katalizującym procesy odnowy strategicznej organizacji węzłowych. Potwierdzają to również badania empiryczne prowadzone $\mathrm{w}$ przedsiębiorstwach sieciowych [Baden-Fuller, Volberda 1997]. Z drugiej strony jednak uczestnictwo w sieci międzyorganizacyjnej może stanowić barierę, hamować lub spowalniać procesy transformacyjne. Niewątpliwie więc sieć międzyorganizacyjna jako czynnik egzogeniczny wywiera wpływ na przemiany dokonywane w systemach zarządzania jej uczestników, choć kierunek i siła tego oddziaływania zależą od wielu zmiennych kontekstowych.

Na podstawie analizy cech sieci międzyorganizacyjnej oraz istoty (specyfiki) procesu odnowy strategicznej możemy wnioskować, że uczestnictwo w sieci będzie wspomagać i przyspieszać odnowę strategiczną w sytuacjach, gdy:

- $\quad$ sieć międzyorganizacyjna jako całość (integrator, pozostali uczestnicy) potrzebuje do poprawy własnych wyników lub dalszego rozwoju nowych produktów, zasobów lub kompetencji, niemożliwych do wytworzenia bez przeprowadzenia odnowy strategicznej jednego lub większej liczby uczestników sieci,

- efekty odnowy strategicznej, np. w postaci szybkości realizacji głównych procesów lub poprawy jakości procesów lub produktów, będą odczuwane nie tylko przez wybrany węzeł sieci, lecz także przez pozostałych jej uczestników (tzn. jeśli pozostali uczestnicy sieci odniosą w związku z odnową wymierne korzyści),

- odnowiony model biznesowy poprawi pozycję konkurencyjną całej sieci. Jak podkreślają niektórzy autorzy, konkurencja przenosi się obecnie z poziomu międzyorganizacyjnego na poziom konkurowania pomiędzy całymi sieciami [D’Aveni 1994; Łobejko (red.) 2012],

- przeprowadzane zmiany strategiczne mają charakter odnowy zewnętrznej, a źródłem nowych możliwości są uczestnicy sieci,

- odnowa strategiczna ma charakter ciągły, co pozwala innym uczestnikom dostosować się do zmieniających się warunków funkcjonowania i współpracy,

- obecny model biznesowy danego przedsiębiorstwa-węzła jest nieefektywny i brak zmian w tym zakresie może zagrażać istnieniu pozostałych uczestników oraz sieci jako całości lub obniżać ich efekty.

Z drugiej strony uczestnictwo w sieci może utrudniać i spowalniać odnowę strategiczną oraz zmniejszać uzyskiwane dzięki transformacji efekty (pozytywne). Może to mieć miejsce szczególnie w sytuacji, gdy:

\footnotetext{
${ }^{1}$ W celu analizy wybrano jedynie trzy najważniejsze, z perspektywy dalszych rozważań, kryteria podziału sieci międzyorganizacyjnych i konsekwentnie wynikające $\mathrm{z}$ ich zastosowania rodzaje sieci międzyorganizacyjnych.
} 
- Odnowa strategiczna inicjowana jest przez jednego z uczestników, ale dotyczy wszystkich (lub wielu z nich) i dla powodzenia tego procesu konieczne są jednoczesne zmiany w wielu podmiotach. Pojawia się wówczas dość istotny problem dotyczący integracji i koordynacji działań w procesie odnowy [Taylor, Helfat 2009]. Tego rodzaju koordynacja wymaga bowiem podejścia odmiennego od tradycyjnej koordynacji, bazującej na hierarchii. Konieczne jest aktywne zaangażowanie kierownictwa wszystkich szczebli i obszarów zarówno po stronie integratora, jak i pozostałych uczestników sieci, swobodna wymiana informacji i współpraca międzyorganizacyjna przy jednoczesnym zachowaniu autonomii działania i inicjatywy uczestników sieci [Volberda 1997; Capron, Mitchell 2009]. Brak kompetencji i doświadczenia w integracji i koordynacji tak szerokich zmian pod względem zakresu i skutków może stanowić barierę w procesie odnowy uczestników sieci. Podobne zjawiska miały miejsce w organizacjach wielooddziałowych, takich jak wspomniany wcześniej IBM, a także Eastman Kodak, Philips czy ING, w których obawa przed potencjalnymi trudnościami koordynacyjnymi ograniczała zakres zmian i osłabiała motywację kadry kierowniczej do przeprowadzania procesów odnowy strategicznej [Volberda, Baden-Fuller, van den Bosch 2001; Tushman, O’Reilly, Harreld 2013].

- Odnowa strategiczna organizacji-węzła polega na wejściu na zupełnie nowy, wyższy poziom technologiczny (a tym samym wyprzedzenie pod tym względem partnerów w sieci i tzw. ucieczkę technologiczną). Obawa przed trudnościami w nadążeniu za partnerami może powodować uruchamianie działań hamujących i spowalniających zmiany ze strony partnerów sieciowych.

- Odnowa strategiczna przedsiębiorstwa doprowadzi do zmiany jego statusu, np. z uczestnika w integratora sieci. Bez względu na osiągane dzięki temu efekty, np. zwiększenie efektywności całej sieci, może być to czynnik ograniczający (dotychczasowy integrator sieci może bronić swojej dominującej pozycji i tym samym hamować zmiany).

- Korzyści wynikające z procesu transformacji będą dotyczyć wyłącznie podmiotu poddanego transformacji i zostaną przez niego „skonsumowane”, tj. nie przełożą się np. na rozwój sieci i innych uczestników.,

- Odnowa ma charakter nieciągły (discontinuous) i towarzyszy jej związana z tym niepewność pozostałych uczestników sieci.

- Proces odnowy danego podmiotu subiektywnie oceniany jest przez pozostałych uczestników sieci jako ryzykowny, a ewentualne niepowodzenia zagrażać mogą nie tylko podmiotowi poddawanemu transformacji, ale również pozostałym uczestnikom sieci.

- Efektem odnowy strategicznej może być opuszczenie danej sieci przez poddany transformacji podmiot i wejście w nowy układ relacji z innymi podmiotami. Jeśli zmiana taka może powodować uszczuplenie zasobów sieci lub odpływ umiejętności, może to rodzić niepewność i uruchamiać bariery po stronie pozostałych uczestników.

Przedstawiona lista przykładowych sytuacji, w których sieć międzyorganizacyjna wspomaga lub ogranicza procesy odno- wy strategicznej organizacji węzłowych, nie jest oczywiście zamknięta. Jest to jedynie propozycja autora do dalszej dyskusji, w której wskazano jedynie wybrane czynniki i okoliczności mające wpływ na realizację procesów odnowy strategicznej. Przedstawiony problem jest niewątpliwie bardzo złożony i trudny do rozwiązania, warto jednak podjąć rozważania naukowe i inicjować badania empiryczne w tym obszarze. Prezentowany artykuł może być zatem jedynie impulsem do szerszej i ugruntowanej empirycznie identyfikacji wpływu uczestnictwa w sieci międzyorganizacyjnej na treść, proces i efekty zmian kluczowych składników modelu biznesowego.

\section{Podsumowanie}

Odnowa strategiczna przedsiębiorstw jest kompleksowym, złożonym i wieloaspektowym procesem transformacji kluczowych składników modelu biznesowego przedsiębiorstwa. Na realizację i powodzenie tego procesu wpływa wiele czynników o charakterze wewnętrznym i zewnętrznym, a jednym z takich czynników (egzogenicznych) jest sieć międzyorganizacyjna.

Uczestnictwo w sieci międzyorganizacyjnej może zarówno wspomagać, jak też hamować proces odnowy strategicznej organizacji węzłowej. Można najogólniej przyjąć, że wspomaganie procesu odnowy strategicznej uczestnika sieci będzie miało miejsce $\mathrm{w}$ sytuacjach, gdy efekty prowadzonych zmian przyniosą korzyści sieci jako całości i jej poszczególnym uczestnikom, w postaci np. usprawnienia procesów, poprawy jakości produktu czy wyników ekonomicznych. W sytuacjach, gdy transformacja danego podmiotu przekładać się będzie wyłącznie na jego własne korzyści, wymagać podjęcia dodatkowych zadań ze strony pozostałych uczestników, oznaczać zmianę jego statusu w sieci lub wzrost ryzyka działalności dla wszystkich uczestników - można spodziewać się, że sieć (jej uczestnicy) będzie dążyć do spowolnienia i ograniczenia zmian ujętych w procesie odnowy strategicznej.

Mając na uwadze powyższe konstatacje, warto zaznaczyć, że przeprowadzenie procesu odnowy strategicznej w warunkach uczestnictwa danego podmiotu w sieci międzyorganizacyjnej wymaga większej uważności na sygnały z otoczenia bliższego (sieciowego), podjęcia intensywnych działań integrujących i koordynujących procesy transformacji, a także poprawy komunikacji i zacieśnienia współpracy pomiędzy uczestnikami sieci. Skuteczność procesu odnowy zależy w dużym stopniu od umiejętności całościowego spojrzenia i sterowania procesem odnowy strategicznej, a to wymaga zastosowania podejścia systemowego do zmian organizacyjnych [Cyfert 2012]. Przedstawione rozważania bazują na studiach literatury i doświadczeniach badawczych autora, źródłach wtórnych i mają charakter teoretyczny. Wysunięte wnioski mogą zatem stanowić jedynie podstawę do sformułowania wstępnych hipotez badawczych w tym zakresie.

\section{Literatura}

Agarwal R., Helfat C.E., 2009, Strategic renewal of organizations, Organization Science, vol. 20, no 2.

Argote L., 1999, Organizational Learning. Creating, retaining and transferring knowledge, Kluwer Academic Publishers, Norwell, MA. 
Baden-Fuller Ch., Volberda H., 1997, Strategic renewal. How large complex organizations prepare for the future, International Studies of Management \& Organization, vol. 27, no 2.

Banaszyk P., Cyfert Sz., 2007, Strategiczna odnowa organizacji, Difin, Warszawa.

Basu S., 2011, Growth options and exit decisions: Does external venturing generate discontinuous strategic renewal?, Academy of Management, January.

Bełz G., 2012, Potencjał dostosowawczy w procesach odnowy przedsiębiorstw, Przegląd Organizacji, nr 11.

Borgatti S.P., Foster P.C., 2003, The network paradigm in organizational research: A review and typology, Journal of Management, vol. 29, no 6

Capron L., Mitchell W., 2009, Selection capability: How capability gaps and internal social frictions affect internal and external strategic renewal, Organization Science, vol. 20, no 2.

Castells M., 2010, The Rise of The Network Society. The information age: economy, society, and culture, Wiley-Blackwell, Oxford.

Cyfert Sz., 2012, Systemowy model organizacji: perspektywa procesów odnowy organizacyjnej, [w:] Strategie i mechanizmy odnowy przedsiębiorstw, Prace Naukowe Uniwersytetu Ekonomicznego we Wrocławiu, nr 276, Wrocław.

Cyfert Sz., Bełz G., Wawrzynek Ł., 2014, Wpływ burzliwości otoczenia na efektywność procesów odnowy organizacyjnej, Organizacja i Kierowanie, $1 \mathrm{~A}(159)$.

Czakon W., 2012, Sieci w zarządzaniu strategicznym, Wolters Kluwer, Warszawa.

D’Aveni R.A., 1994, Hypercompetition, Free Press, New York.

Delporte-Vermeirena D , Vervest P., van Heck E., 2004, In search of margin for business networks: The European Patent Office, European Management Journal, vol.. 22, no 2 .

Gibbons D.E., 2004, Network structure and innovation ambiguity effects on diffusion in dynamic organizational fields, Academy of Management Journal, vol. 47, no 6 .

Gulati R., Gargiulo M., 1999, Where Do Interorganizational networks come from?, American Journal of Sociology, vol. 104, no 5.

Harrigan K., Newman W., 1990, Basis of interorganization co-operation: Propensity power and persistence, Journal of Management Studies, vol. 27 (4), July.
Krupski R. (red.), 2005, Zarządzanie przedsiębiorstwem $w$ turbulentnym otoczeniu, PWE, Warszawa.

Łobejko S. (red.), 2012, Przedsiębiorstwa sieciowe i inne formy współpracy sieciowej, Oficyna Wydawnicza SGH, Warszawa.

Madhavan R., Koka B.R., Prescott J.E., 1998, Networks in transition: How industry events (re)shape interfirm relationships, Strategic Management Journal, vol. 19, no 5 .

Milward H.B., Provan K.G., 2006, A Manager's Guide to Choosing and Using Collaborative Networks, IBM Center for the Business of Government, Washington.

Niemczyk J., Stańczyk-Hugiet E., Jasiński B. (red.), 2012, Sieci międzyorganizacyjne. Współczesne wyzwanie dla teorii i praktyki zarządzania, C.H. Beck, Warszawa.

Powell W., Koput K., Smith-Doerr L., 1996, Inter-organizational collaboration and the locus of innovation: Networks of learning in biotechnology, Administrative Science Quarterly, vol. 41, no 1.

Taylor A., Helfat C.E., 2009, Organizational linkages for surviving technological change: Complementary assets, middle management, and ambidexterity, Organization Science, vol. 20, no 4.

Thorelli H.B., 1986, Networks: Between markets and hierarchies, Strategic Management Journal, vol. 7, no 1.

Tushman M., O’Reilly Ch., Harreld B., 2013, Leading strategic renewal: Proactive punctuated change through innovation streams and disciplined learning, http://www.hbs.edu/faculty/conferences/2013-change-andsustainability/Documents/Tushman,O'Reilly,Harreld.pdf.

Uzzi B., Lancaster R., 2003, Relational embededdness and learning: The case of bank loan managers and their clients, Management Science, vol. 49, no 4.

Volberda H.W., 1997, Strategic Renewal in Large Multiunit Firms: Four dynamic mechanisms, OECD Workshop, Paris.

Volberda H.W., Baden-Fuller Ch., van den Bosch F.A.J., 2001, Mastering strategic renewal. Mobilising renewal journeys in multi-unit firms, Long Range Planning, vol. 34.

Williamson O.E., 1998, Ekonomiczne instytucje kapitalizmu. Firmy, rynki, relacje kontraktowe, Wydawnictwo Naukowe PWN, Warszawa. 